\title{
Peran Kelompok Usaha Bersama (KUB) dalam Meningkatkan Kesejahteraan Nelayan di Pantai Ketaping Kecamatan Batang Anai Kabupaten Padang Pariaman
}

\author{
Nur Sa'adah, Isnarmi \\ Prodi Pendidikan Pancasila dan Kewarganegaraan \\ FIS Universitas Negeri Padang \\ E-mail: Noerrsaadah6812@gmail.com
}

\section{ABSTRAK}

Penelitian ini bertujuan untuk mendeskripsikan peran dan hambatan dari Kelompok Usaha Bersama (KUB) Mutiara Laut untuk meningkatkan kesejahteraan nelayan di Pantai Ketaping Kecamatan Batang Anai Kabupaten Padang Pariaman. Penelitian ini merupakan penelitian kualitatif dengan mengunakan metode deskriptif karena penelitian ini berusaha mengambarkan dan melukiskan fakta-fakta secara akurat tentang suatu keadaan atau peristiwa yang tampak pada KUB Mutiara Laut. Teknik pengumpulan data yang digunakan adalah observasi,wawancara dan studi dokumentasi. informan penelitian adalah ketua KUB, sekretaris KUB, bendahara KUB, anggota KUB dan Dinas Perikanan. Uji keabsahan data dalam penelitian ini mengunakan teknik triangulasi data. Kemudian Teknik analisis data dilakukkan dengan empat alur kegiatan yaitu pengumpulan data, reduksi data, penyajian data dan kesimpulan. Hasil penelitian menunjukkan bahwa terdapat peran dari Kelompok Usaha Bersama (KUB) untuk meningkatkan kesejahteraan nelayan di di Pantai Ketaping. Adanya Program Kelompok Usaha Bersama( KUB) untuk nelayan masih belum maksimal karena ada beberapa kendala dalam program kegiatan Kelompok Usaha Bersama (KUB) diantaranya pada program pembiayaan dan permodalan yang mana disini adannya kurang rasa tangung jawab untuk menjaga alat yang telah diberikan pemerintah, adannya kecemburuan sosial. Selanjutnya pada program pendidikan, pelatihan dan penyuluhan disini adanya kesibukan masing-masing anggota sehingga tidak hasir dalam pelatihan ataupun rapat.

Kata Kunci: nelayan, kesejahteraan, KUB

\section{ABSTRACT}

This study aims to describe the roles and obstacles of the KUB Mutiara Laut to improve the welfare of fishermen in Ketaping Beach, Batang Anai District, Padang Pariaman Regency. This research is a qualitative research using descriptive method because this research attempts to describe and describe facts accurately about a situation or event that appears at KUB Mutiara Laut. The data collection techniques used were observation, interview and documentation study. Research informants are the head of KUB, secretary of $K U B$, treasurers of $K U B$, members of $K U B$ and the Department of Fisheries. Data validity 
test in this study used data triangulation techniques. Then the data analysis technique was carried out with four activity lines, namely data collection, data reduction, data presentation and conclusions. The results show that there is a role for the KUB to improve the welfare of fishermen in Ketaping Beach. The existence of the KUB for fishermen is still not optimal because there are several obstacles in the KUB activity program, including the financing and capital program where there is a lack of responsibility to maintain the tools that have been provided by the government, jealousy. social. Furthermore, in education, training and counseling programs, each member is busy so that he is not enthusiastic in training or meetings.

Keywords: Fishermen, Welfare and KUB

\section{PENDAHULUAN}

Indonesia adalah negara yang memiliki potensi kelautan yang sangat yang berangam serta bernilai ekonomi tinggi sehingga berpotensi untuk meningkatkan kesejahteraan masyaraat khususnya masyarakat nelayan. Namun pada kenyataannya laut Indonesia belum bisa dimanfaatkan seutuhnya oleh masyarakat nelayan. Keterbatasan pengetahuan serta alat yang digunakan membuat masyarakat nelayan tidak mendapatkan hasil yang banyak, sehingga masyarakat nelayan tidak dapat memenuhi kebutuhan hidupnya. Dengan kondisi kekayaan laut yang melimpah serta masyarakat nelayan yang masih banyak tergolong miskin disebabkan hasil tangkapan yang tidak memenuhi kebutuhan hidupnya serta pengetahuan yang minim saat melaut maka pemerintah membuat program Kelompok Usaha Bersama (KUB) bagi masyarakat nelayan.

Hasil penelitian Syahma (2016:31) tentang Analisis faktor-faktor yang memepengaruhi pendapatan nelayan menemukan bahwa masyarakat nelayan identik dengan kemiskinan yang disebabkan kurangnya modal, teknologi, rendahnya akses terhadap pasar, serta rendahnya partisipasi masyarakat untuk mengolah sumber daya alam. Kemudian hasil penelitian dari Nur Fadhilah T (2016:45-47) tentang Peranan masyarakat nelayan terhadap peningkatan ekonomi menemukan bahwa upaya untuk kesejahteraan ekonomi masyarakat nelayan kanje harus berperan serta dalam upaya peningktan rumah tangga, ekonomi, pendidikan anak, dan masyarakat juga harus ikut serta dalam pembinaan manusia untuk mewujudkan supaya kehidupan nelayan akan lebih baik.

Penelitian ini akan fokus pada peran KUB dalam meningkatkan kesejahteraan nelayan di Pantai Ketaping Kecamatan Batang Anai Kabupaten Padang Pariaman. Adapun manfaat yang diharapkan setelah penelitian ini adalah dapat berguna untuk memberikan masukan bagi 
masyarakat nelayan serta diharapkan dapat membantu memberikan informasi yang berarti bagi kemajuan anggotanya. Diharapkan pula dapat memberikan sumbangan yang positif bagi tercapainya hasil yang diinginkan. Dapat pula dijadikan pertimbangan untuk kemajuan KUB.

\section{METODE PENELITIAN}

Penelitian ini mengunakan jenis penelitian kualitatif dengan mengunakan metode deskriptif, yaitu suatu jenis penelitian membuat suatu gambaran dan lukisan suatu keadaan yang bersifat sistematik dan akurat mengenai fakta-fakta,sifat-sifat serta hubungan antara fenomena yang diteliti sesuai dengan keadaan yang sebenarnya. Sepuluh orang angggota KUB sebagai sumber data, yang terdiri dari satu orang Ketua, satu Sekretaris, Satu Bendahara dan tujuh orang sebagai anggota kelompok. Data ini dikumpulkan menggunakan teknik observasi, teknik wawancara dan studi dokumentasi. Selanjutnya data dianalisis menggunakan teknik analisa kualitatif interaktif sebagaimana di gambarkan oleh Miles dan Huberman dalam Afifuddin (1992:15-20) yang harus dilakukkan dalam analisa kualitatif interaktif adalah pengumpulan data, reduksi data dan penarikan kesimpulan.

\section{HASIL DAN PEMBAHASAN}

\section{Peran KUB Untuk Meningkatkan Kesejahteraan Masyarakat nelayan}

Menurut Robbins \& Judge (2015:185) peran adalah sebuah prilaku seseorang yang memiliki posisi tertentu yang dalam suatu kegiatan. Menurut Zulkarnain (2013:10) peran menjamin bahwa dalam menjalankannya, setiap anggota saling berinteraksi sehingga tujuan kelompok dapat tercapai. Peran tersebut saling melengkapi, sehingga suatu peran tidak dapat tercapai tanpa adanya peran lain. Sehubungan dengan itu Menurut Herawati (2012:19-23), peran KUB adalah meningkatnya taraf kesejahteraan masyarakat, terpenuhinya kebutuhan, meningkatnya keterampilan, Berkembangnya kerjasama, dan meningkatnya pendapatan nelayan. Peran KUB Mutiara Laut dapat dilihat melalui beberapa program diantaranya (a) pembiayaan dan permodalan. (b) pendidikan, pelatihan dan penyuluhan. (c) kemitraan. (d) pengakapan ikan oleh nelayan.

Pelaksanaan program KUB ditandai oleh beberapa kegiatan yang telah dilaksanakan yaitu penyuluhan cara penangkapan ikan dan pengawetan ikan dari Dinas Perikanan, pelatihan membuat jaring, pelatihan membongkar mesin dan pengawetan ikan yang diberikan melalui pelatihan kewirausahaan, pemberian modal oleh pemerintah untuk kelompok nelayan dan rapat anggota. Dari beberapa kegiatan tersebut dapat dilihat beberapa peran KUB Mutiara Laut adalah yang pertama meningkatkan pengetahuan yang ditandai dengan adanya pengetahuan nelayan tentang melaut dan pengawetan ikan. Kedua meningkatkan kemampuan sosial yang ditandai dengan terjalinnya hubungan sosial yang baik antara anggota Kelompok maupun masyarakat sekitar serta adanya pertukaran informasi dalam sebuah kelompok nelayan yang dapat mempererat silaturahmi antara kelompok. Ketiga meningkatkan keterampilan nelayan yang ditandai 
dengan keterampilan nelayan dalam memperbaiki peralatan melaut dan dalam menjaga kesegaran ikan. Keempat meningkatkan kesejahteraan anggota yang dibuktikan dengan adanya kelompok yang telah memilki usaha sendiri dan pendapatannya setelah melaut dapat memenuhi kebutuhan sehari-hari.

\section{Hambatan Dalam KUB Mutiara Laut}

Penelitian Syahma (2016:31) menyatakan nelayan identik dengan kemiskinan yang disebabkan kurangnya modal, teknologi dan rendahnya partisipasi masyarakat untuk mengolah sumber daya alam. Penyataan tersebut memang dialami nelayan di Pantai Ketaping dimana sebelum menjadi anggota KUB Mutiara Laut nelayan di Pantai ketaping kesulitan untuk melaut karena kurangnnya modal mengakibatkan tidak lengkap peralatan melaut nelayan, sehingga dengan demikian hasil tangkapan nelayan tidak banyak.

Setelah menjadi angota KUB Mutiara Laut nelayan mendapatkan pelatihan-pelatihan dan penyuluhan dari pemerintah serta diberikan modal baik uang tunai maupun alat melaut agar hasil tangkapannya meningkat dari biasanya karena teknologi yang digunakan sudah modern. Walaupun sudah menjadi anggota KUB Mutiara Laut tetap saja ada hambatan dalam menjalankan kegiatan dalam sebuah kelompok. Menurut Hermawati (2012:128-132), faktor penghambat pelaksanaan KUB adalah rendahnya tingkat pendidikan anggota kelompok dan adanya sikap iri hati.
Berdasarkan penelitian peneliti di Pantai Ketaping disimpulkan bahwa hambatan dalam melaksanakan program KUB Mutiara Laut diantaranya adalah pertama kurangnya rasa tanggung jawab menjaga alat dari bantuan pemerintah dan kecemburuan sosial yang terjadi antara anggota kelompok apabila ada pencairan dana. Kedua dalam program pendidikan, pelatihan dan penyuluhan yang dapat dilihat dari adanya kesibukan masingmasing anggota yang terlihat jelas dari beberapa anggota tidak pergi menghadiri pelatihan maupun rapat anggota karena adanya pekerjaan yang tidak bisa di tinggalkan.

\section{KESIMPULAN}

Berdasarkan uraian diatas, dapat penulis simpulkan bahwa peran KUB dalam meningkatkan kesejahteraan nelayan adalah dengan mengadakan kegiatan pemberdayaan bagi nelayan diantarannya pembiayaan dan permodalan, (b) pendidikan, pelatihan dan penyuluhan, (c) kemitraan dan (d) penangkapan ikan oleh kelompok. Jadi dengan adanya program KUB maka dapat meningkatkan keterampilan kelompok, kedua meningkatkan pengetahuan kelompok, ketiga meningkatkan sikap sosial kelompok dan keempat meningkatkan kesejahteraan kelompok yang ditandai dengan bertambah hasil pendapatan kelompok dan Sumberdaya Manusia. Kendala yang ada dalam pelaksanaan program KUB Mutiara Laut adalah pertama dalam program pembiayaan dan permodalan. Kedua beberapa anggota tidak pergi menghadiri pelatihan maupun rapat anggota karena adanya pekerjaan yang tidak bisa di tinggalkan. 


\section{DAFTAR PUSTAKA}

Afifudin. 2012. Metodologi Penelitian Kualitatif. Bandung: CV. Pustaka Setia

Hermawati Roebyantho, Dkk. 2011. Dampak Sosial Ekonomi Program Penanganan Kemiskinan Melalui KUB. Jakarta: P3KS.

Kusnadi. 2007. Trategi Hidup Masyarakat Nelayan. Yogyakarta : PT. Lkis Pelanggi Aksara Yogyakarta.

Leilani, Ani. 2016. Partisipasi Nelayan Dalam Kelompok Usaha Bersama Bidang Penangkapan Ikan (Kasus Pada KUB Di Kecamatan Pangandaran, Kabupaten Pangandaran). Jurnal Penyuluhan Perikanan Dan Kelautan. Volume 10 Nomor 1.

Nurfadhila, T. 2016. Peranan Masyarakat Nelayan Terhadap Peningkatan Ekonomi Di Desa Kenjekecamatan Campalagian Kabupaten Polewali Mandar. Jurnal Jurusan Ekonomi Dan Bisnis Islam Universitas Islam Negeri Alauddin Makassar.

Peraturan Pemerintah Republik Indonesia Nomor 50 Tahun 2015 Tentang Perubahan Atas Undang-Undang Republik Indonesia Nomor 31 Tahun 2004 Tentang Perikanan. Diakses
Tanggal $24 \quad$ November 2019.Pukul 08.33 WIB.

Suprihatin. 2017. Fungsi Kelompok Usaha Bersama Dalam Pemberdayaan Komunitas Pedagang Di Kelurahan Imopuro Kecamatan Metro Pusat Kota Metro. Jurnal Fakultas Dakwah Dan Ilmu Komunikasi. Institut Agama Islam Negeriraden Intan. Universitas Islam Negeri Alauddin Makassar.

Syahma, Asmita. 2016. Analisis FaktorFaktor Yang Mempengaruhi Pendapatan Nelayan Tangkap Di Desa Galesong Kota Kecamatan Galesong Kabupaten Takalar. Jurnal Jurusan Ekonomi Pembangunan Fakultas Ekonomi Universitas Negeri Makassar. Universitas Negeri Makassar.

Wardianti. 2009. Peran KUB Meningkatkan Kesejahteraan Masyarakat Dalam Prespektif Ekonomi Islam ( Studi Di Kecamatan Baradatu Kabupaten Way Kanan). Jurnal Jurusan Ekonomi Dan Bisnis Islam Universitas Islam Negeri Alauddin Makassar. Universitas Islam Negeri Alauddin Makassar. 